\title{
Tingidae (Hemiptera: Heteroptera) from Laos: new species and new records
}

\author{
ERIC GUILBERT
}

Muséum national d'Histoire naturelle,Département de Systématique et Evolution, UMR 5202SM 601, CP50 45 rue Buffon, 75005 Paris, France. E-mail: guilbert@mnhn.fr, tel/fax: (33) 1.40.79.34.11 / 56.79

\begin{abstract}
Eight species new to science are described from Laos, and 19 species are newly recorded from Laos. A key to genera and species is provided.
\end{abstract}

Key words: Heteroptera, identification key, Laos, new species, new records, systematics, taxonomy, Tingidae

\section{Introduction}

Until now, Tingidae from Laos have been known from only a single paper, which describes two new species of Cantacaderinae (Lis 1999). A survey in Phong Sali province and material from the B.P. Bishop Museum from several collecting trips, allow me to record 19 species new to Laos, and to describe eight species new to science, namely Agramma biseriata sp. n., Elasmognathus laosensis sp. n. (including the fifth instar), Lasiacantha gressitti sp. n., Paracopium longnaimai sp. n., Penottus minicystus sp. n. (including the fifth instar), Phatnoma natensis sp. n. (including the fifth instar), Trachypeplus elongatus sp. n., Trachypeplus wapi $\mathbf{s p .} \mathbf{n}$. All type material from Phong Sali province is deposited at the Muséum National d'Histoire Naturelle (MNHN), Paris; the other type material is deposited at the Bernice P. Bishop Museum, Honolulu. All measurements are in millimeters. In the list of material examined, $\mathrm{F}$ means female and $\mathrm{M}$ male.

\section{Description of new species}

\section{Agramma biseriata sp. n.}

(fig. 1)

Material examined: 1 ㅇ, Laos, Vientiane prov., Ban Van Eue, 15.XII.1965, malaise trap, native coll., Rondon-Bishop.

Description: body long, narrow, glabrous, shiny; head, pronotum except tip of posterior pronotal process, sternum, abdomen, antennae dark brown, abdomen clearer; legs, hemelytra, tip of posterior pronotal process, anterior margin of collar, frontal spines yellowish. Body length, 2.33; width, 0.83.

Head longer than wide, punctate on top, flat, armed with pair of short frontal spines directed forwards; bucculae slightly produced in front of clypeus, joined in front, short and wide, with two rows of areolae, several tiny areolae in a third row; rostrum short, stout, extending beyond fore coxae, reaching middle of mesosternum; antennae stout, pilose, antennal segment measurements: I, 0.2; II, 0.17; III, 0.47; IV, 0.23.

Pronotum twice longer than wide, deeply punctate, slightly gibbose, unicarinate, the median carinae not 
areolate, reduced to a ridge; collar triseriate, not raised; paranota almost absent reduced to slight ridge; posterior process long, sharply angulate; sulcus narrow, open behind, laminae with small areolae, mesosternal laminae slightly sinuate; femora bent, narrowed at base, hind tarsi pilose, twice as long as wide.

Hemeytra long, narrow, slightly wider than pronotum but narrowing posteriorly; costal area biseriate throughout length, areolae larger in posterior half; subcostal area as wide as costal area, triseriate, areolae round, smaller than in costal area; discoidal area longer than half length of hemelytra, narrow, four areolae wide at widest part, areolae of same size as in subcostal area; sutural area four to five areolae as wide at widest part, areolae of same size as in costal area.

Etymology: The name refers to the entirely biseriate costal area.

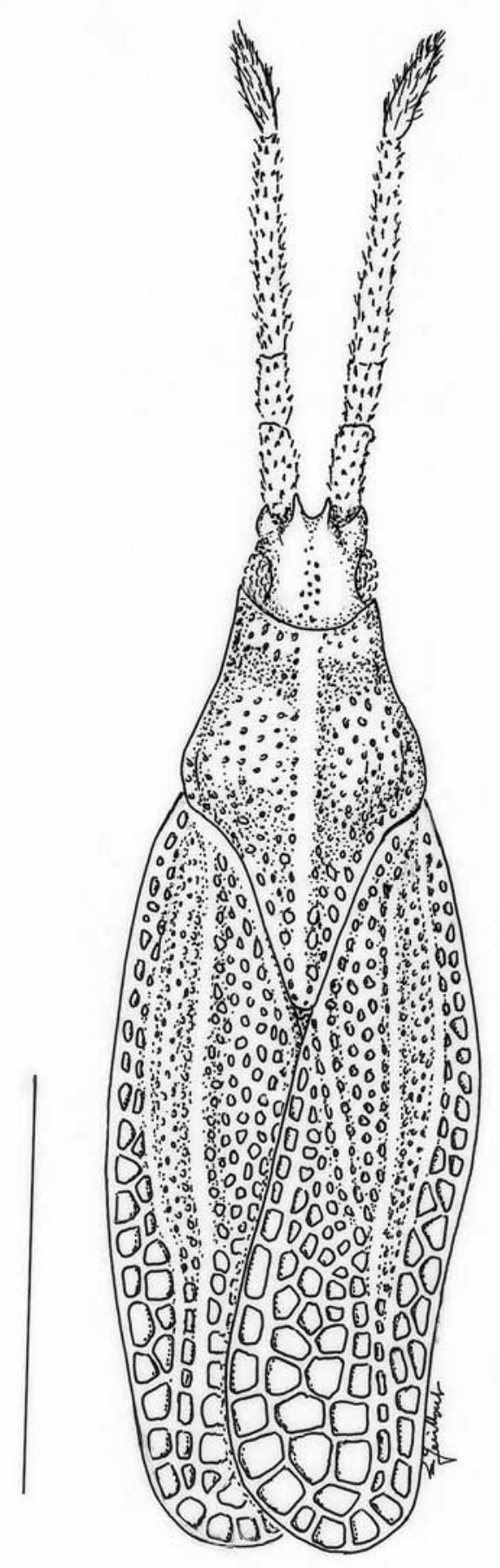

FIGURE 1. Agramma biseriata sp. n., habitus. 
Comments: This species differs from the others by its wide and biseriate costal area. Agramma amplicostatum Rodrigues, danielssoni Péricart, singulum (Drake), and yunnanum Jing all have a costal area partly biseriate, and are narrower than this new species.

\section{Elasmognathus laosensis sp. $\mathbf{n}$.}

(figs. 2, 3, 4)

Material examined: $1{ }^{x}$, 1 fifth instar, Laos, Vientiane, light trap, 24.VI.1960, S. Quate \& L. Quate coll., Bishop.

Adult description: body rather stout, shiny, uniformly clear brown to yellowish, paranota darker, fourth antennal segment and hind tarsi dark brown, body beneath yellowish to whitish. Legs with white spinous process at base of femora. Body length, 4.37; width, 1.60.

Head short, armed with five long slender spines, directed forwards; antenniferous processes spiny, bucculae long, wide, closed in front; antennae long, slender, antennal segment measurements: I, 0.20; II, 0.17; III, 1.5; IV, 0.43; rostral sulcus widened, open posteriorly; rostrum reaching middle of mesosterum.

Pronotum long, tricarinate, median carina raised, uniseriate, lateral carinae six areolae wide, raised, curved inwards, divergent on top of pronotum to form a heart, almost completely concealed by paranota; hood raised, tectiform, eight areolae long, produced forwards above head, less high than top of median carina; paranota well developed, raised, forming two auricles above pronotum, concealing all lateral carinae except posterior extremity, and following their form, but not covering median carina, inner margin curved inwards on margin of lateral carinae.

Hemelytra slightly widened medially, slightly wider than pronotum; costal area bent upwards, irregularly biseriate, posteriorly uniseriate, areolae large; subcostal area uniseriate, with some small additional areolae along; discoidal area more than half length of hemelytra, seven areolae wide at widest part; sutural area narrow, five areolae wide at widest part.

Fifth instar description: Body shiny, clear brown, except body beneath, head, calli, dorsal scent glands area darker, dorsum covered with tiny bulbous processes. Body length, 2.83; width, 1.67; spine maximal length, 0.47 .

Head armed with five long, spiny, erect tubercles; antenniferous processes long, spiny; antennal segment measurements: I, 0.17; II, 0.13; III, 0.97; IV, 0.43.

Pronotum wide, anterolateral margins regularly rounded, armed with five long spiny tubercules regularly spaced; posterior margin without tubercles; median pair of two spiny tubercles near anterior margin, tubercles shorter than marginal ones.

Mesonotum with median pair of short and spiny tubercles near posterior margin; hemelytral pads armed with short basal spiny tubercles and four long, spiny, erect tubercles regularly spaced.

Metanotum with median pair of short and spiny tubercles near posterior margin.

Fourth to ninth abdominal terga armed with a long, spiny and erect tubercle on each side of posterolateral margin; first abdominal tergum with median pair of short, spiny tubercles; second, fifth, sixth terga each with median long spiny tubercle; eighth tegum with median tubercle reduced to bulbous protuberance.

Etymology: The name refers to the country from where is described this species.

Comments: This species is close to E. helferi Fieber but has a discoidal area seven areolae wide, not nine, and a costal area irregularly biseriate, not triseriate. The paranota have the same shape, and the median carina is higher. It is also close to E. auriculatus Péricart in having the costal area irregularly biseriate, but it has different paranota. The spinous process at the base of the femora is sharper in E. auriculata and this species than in E. fieberi Stål and E. helferi. The genus Elasmognathus includes three species, one inhabiting South Africa, the others inhabiting the Oriental region. This is the first immature of the genus described. 


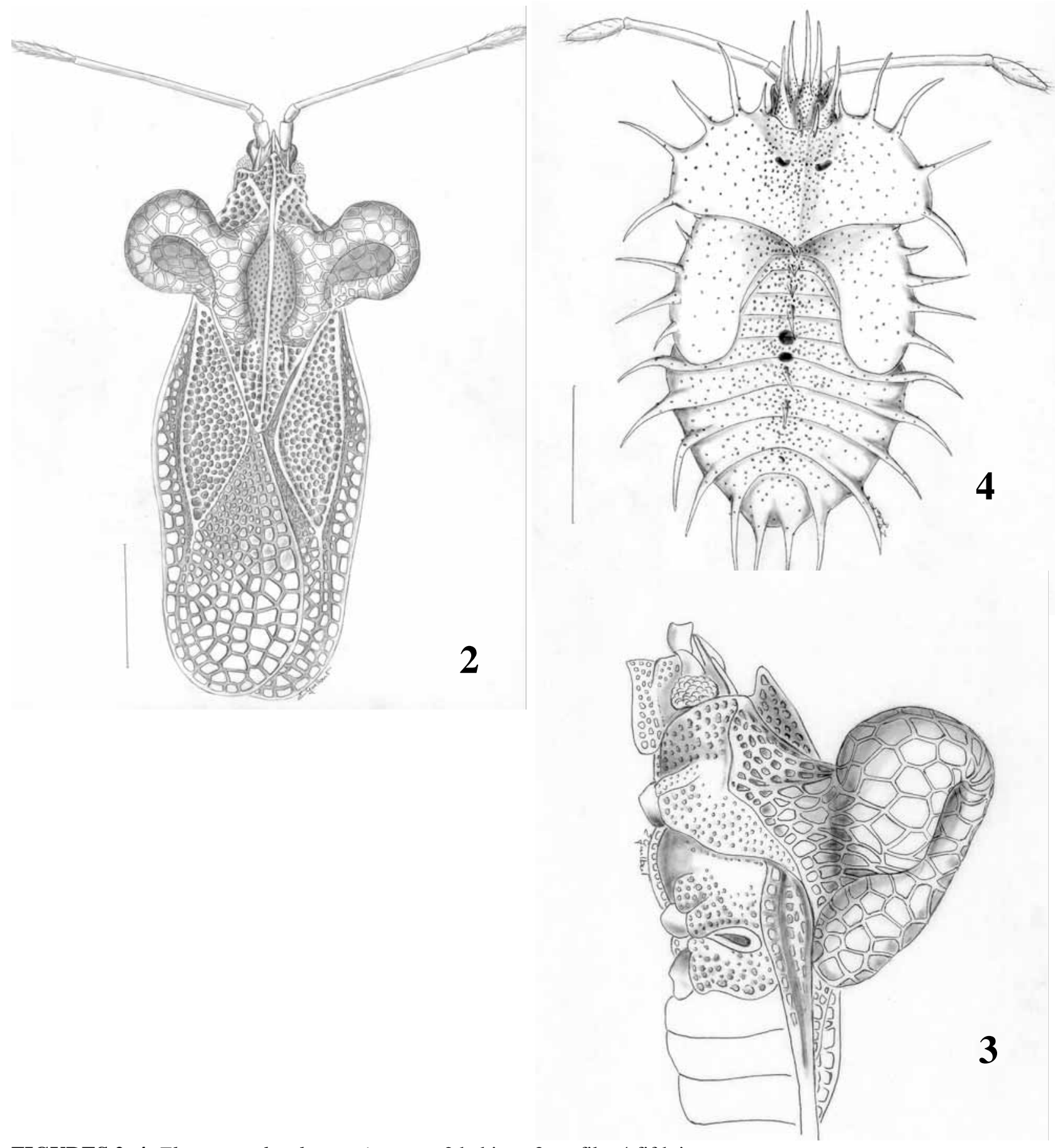

FIGURES 2-4. Elasmognathus laosensis sp. n., 2 habitus, 3 profile, 4 fifth instar.

\section{Lasiacantha gressitti sp. n.}

(fig. 5)

Material examined: 1 ㅇ, Laos, Vientiane prov., Ban Van Eue, 1415.IV.1965, J.L. Gressitt coll., Bishop; 1 o $^{\star}$ 1 , Laos, Vientiane prov., Ban Van Eue, 30.XI.1966, native coll., Bishop.

Description: Body large, wide, shiny, pilose, spiny on margins of hemelytra, pronotal expansions, boundary hemelytral areas, areolae hyaline, reticulation whitish to brownish; transversal band across costal area, peripherical band of discoidal area, middle of median carina, head, hind tarsi darker. Body length, 4.32; width, 2.17 . 
Head armed with five long, slender spines, directed forwards, occipital spines divergent; bucculae long, three areolae wide, closed in front; antennae long, slender, pilose, hairs straight, long, antennal segment measurements: I, 0.17; II, 0.12; III, 1.82; IV, 0.53; rostral sulcus deep, short, laminae curved, wide, with large areolae, open behind; rostrum reaching apex of second visible abdominal segment.

Pronotum slightly gibbose, posterior process short, rounded, tricarinate, median carina raised, foliate, wide, four areolae wide on top of pronotum; lateral carinae raised, foliate, wide, but lower than median carina, uniseriate, areolae large; hood high, narrow, somewhat cyst-like, lower than median carina, four to five areolae high; paranota wide, five areolae wide at widest part, raised, straight, but not reflexed onto pronotum.

Hemelytra large, wide, greatly widened at base; costal area wide, sinuate, four areolae wide at widest part, areolae small anteriorly, large posteriorly; subcostal area narrower than costal area, almost vertical, biseriate, areolae small; discoidal area small, less than half length of hemelytra, five areolae wide at widest part; sutural area narrow, three areolae wide at widest part, areolae large.

Etymology: This species is named in honor of Dr. J. L. Gressitt, who collected a large amount of Tingidae through southeastern Asia and the western Pacific Islands.

Comments: This species is similar to L.cuneata (Distant) and altimitrata (Takeya) but differs by the wider costal area (four areolae wide), and the median carina is higher than the hood.

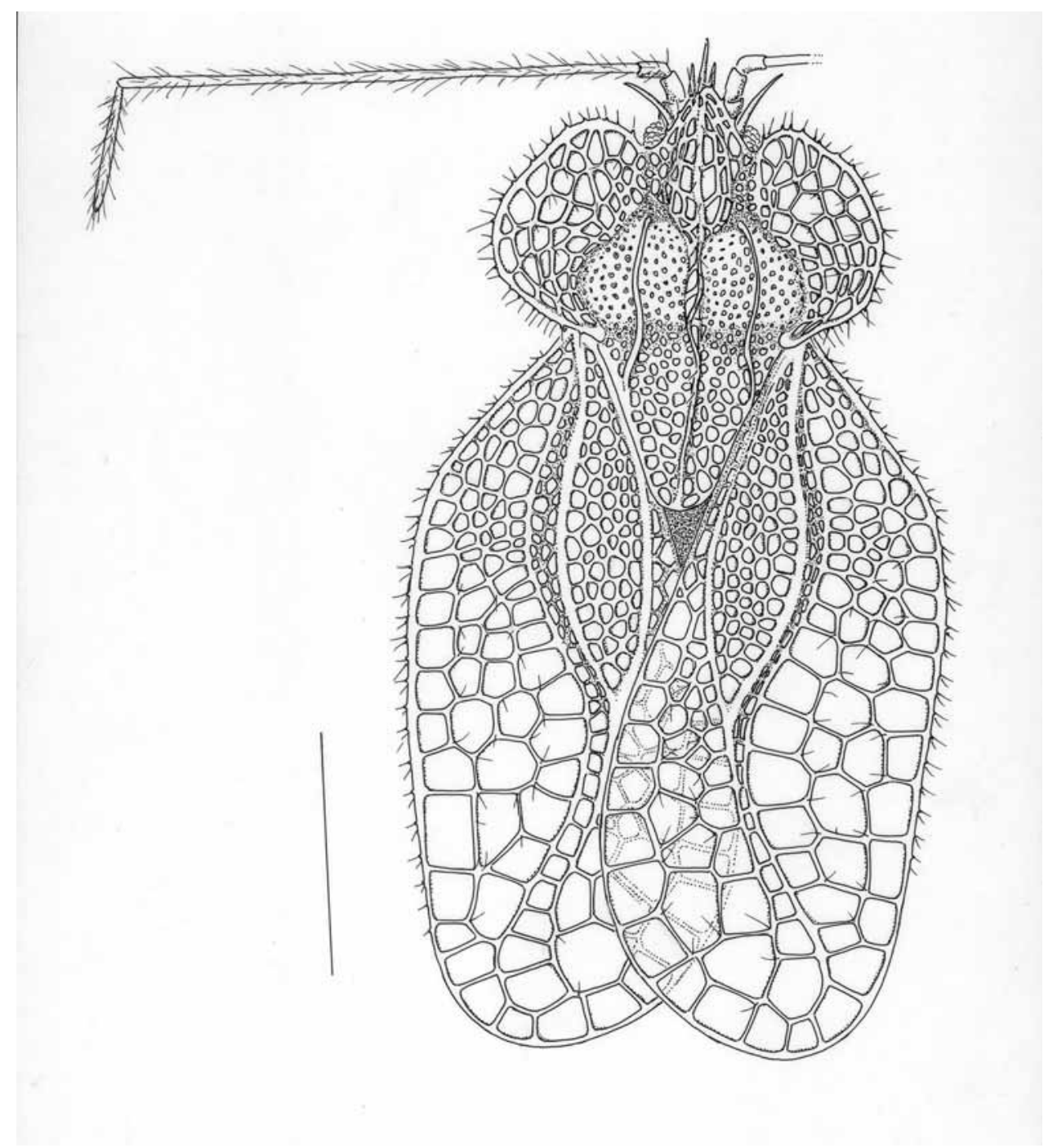

FIGURE 5. Lasiacantha gressitti sp. n., habitus. 


\section{Paracopium longnaimai sp. $\mathbf{n}$.}

(fig. 6)

Material examined: 1 ơ, Laos, Phong Sali prov., Long Nai Mai, 30.IX.2004, Guilbert coll., MNHN.

Description: Body elongate, shiny, brown, with short sparse pilosity; occipital spines, principal hemelytral veins, carinae, collar, paranota clearer; pronotum, head, antennae, legs, body beneath darker. Body length, 5.50; width, 1.73 .

Head long, flat, top of head punctate, with denser pilosity, armed with five spines: an occipital pair of long spines straight and appressed on head, a short stout median spine directed forwards, a frontal pair of short stout spines directed forwards and convergent; postocular plate large, visible; eyes not in contact with collar margin, antennae stout, densely pilose, antennal segment measurements: I, 0.4; II, 0.27; III, 1.53; IV, 1.33; bucculae long, narrow, mostly biseriate, closed in front; rostrum reaching mid coxae.

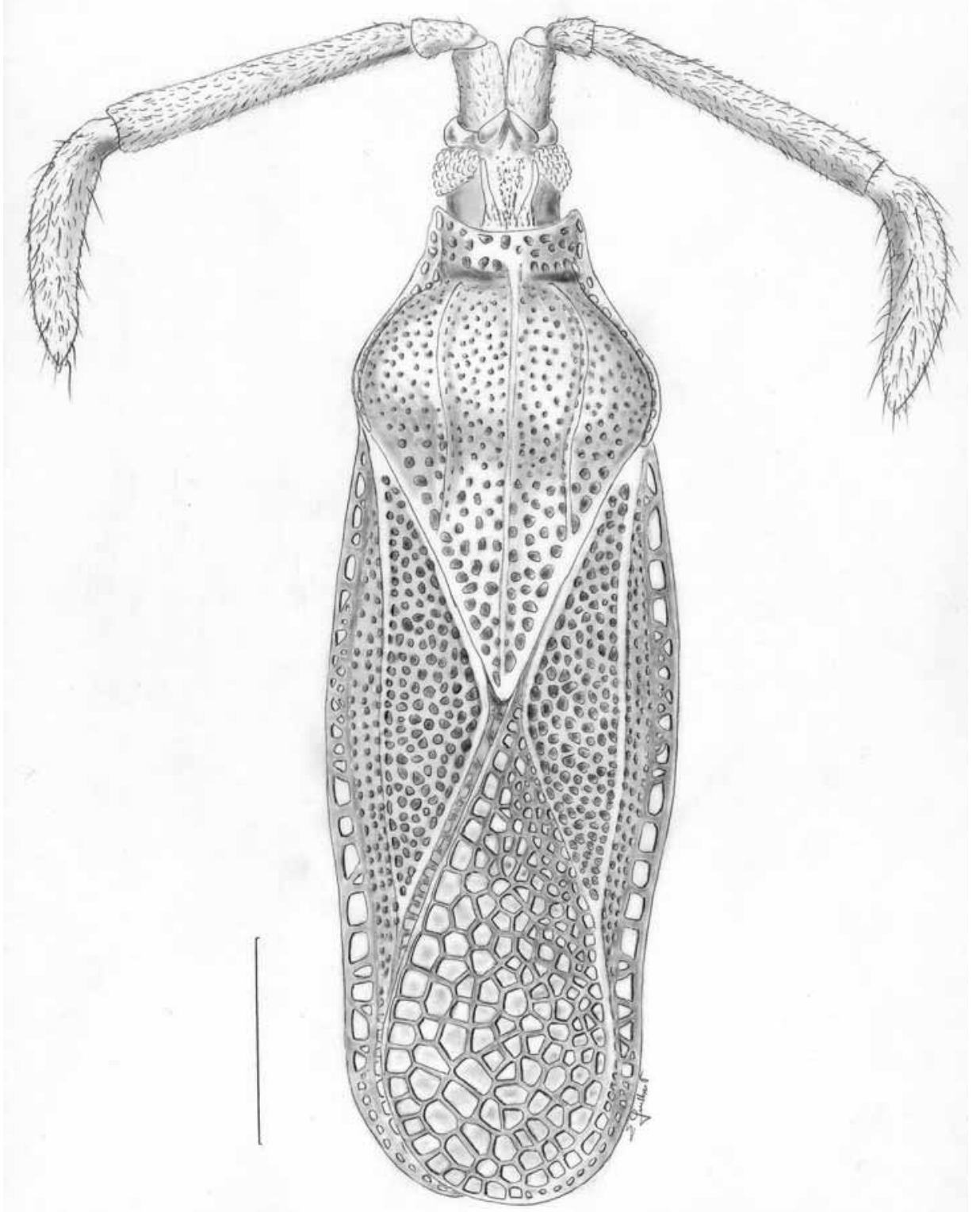

FIGURE 6. Paracopium longnaimai sp. n., habitus.

Pronotum long, gibbose, mostly punctate, areolate on posterior process, tricarinate; carinae subparallel, raised, uniseriate with tiny areolae; collar slightly raised, biseriate; paranota narrow, uniseriate, areolae 
slightly larger than on carinae, an additional inner areolae opposite to calli; rostral sulcus narrow, almost straight, open behind, laminae uniseriate.

Hemelytra narrow, slightly wider than pronotum, costal area uniseriate, areolae irregularly arranged, mostly subquadrate, some round and much smaller, almost in two rows opposite middle of discoidal area; subcostal area wider than costal area, triseriate, areolae round, smaller than in costal area; discoidal area long, more than half length of hemelytra, seven areolae wide at widest part, areolae same size as in subcostal area; sutural area 10 areolae wide at widest part, areolae polygonal, larger than in costal area.

Etymology: The name of this species refers to the type locality.

Comments: this new species is justified by the fact its costal area differs from that of all its congeners. This species is also much longer than the oriental species ( $P$. cingalense (Walker), comentis Drake, philippinensis Drake, lewisi Distant, and sauteri Drake).

\section{Phatnoma natensis sp. $\mathrm{n}$.}

(figs. 7, 8)

Material examined: $1 \sigma^{\star}$, 1 fifth instar, Phong Sali prov., Naten, 13.X.2004, Guilbert coll., MNHN.

Adult description: Body shiny and glabrous; hemelytra and pronotum irregularly clear brown to brown; principal and transversal veins on hemelytra, pronotal carinae and paranota margins and tip of cephalic spines whitish; head, antennae, legs and body beneath yellowish to brown. Body length, 3.80; width, 1.90 .

Head long and narrow, punctate on top, armed with seven long spines, stout at base, directed forwards; tips of occipital pair of spines extending beyond base of frontal ones; frontal pair and median spine stouter than occipital spines; jugal pair shorter than the others; antenniferous processes long and spiny, reaching middle of length of first antennal segment; antennae long and slender, antennal segment measurements: I, 0.10; II, 0.07; III, 1.33; IV, 0.3; bucculae long, extending in front of apex of clypeus, closed in front, three areolae wide, rostrum long reaching second visible abdominal segment.

Pronotum wider than long, gibbose, tricarinate; carinae raised and uniseriate, areolae small; median carina continuing on collar as to form a crest slightly extending in front of anterior margin; collar three areolae wide; paranota wide, six areolae wide on anterior margin, eight areolae wide at widest part, a little erect, produced laterally and in front by an acute angle, anterior angles with a spine, margins between angles roundly excavated, reduced posteriorly; posterior process reduced to a very narrow area of a single row of tiny areolae between lateral carinae; scutellum visible, reduced to a small erect protuberance; peritreme of metathoracic scent gland large and round.

Hemelytra wide, all areolae round and of the same size; costal area wide, six-seven areolae wide, sligthly raised; subcostal area a little narrower than costal area, six areolae wide, divided in six or seven sub-areas by slightly raised transversal veins; discoidal area as wide as subcostal area, six areolae wide, divided in five subareas by slightly raised transversal veins; discoidal area nine areolae wide at widest part; $\mathrm{RM}$ and $\mathrm{Cu}$ veins erect with a row of subrectangular areolae; $\mathrm{RM}$ vein wider than $\mathrm{Cu}$ vein, with a wider black spot in the posterior two-third of the length, with small round and irregularly arranged areolae; hypocostal area mostly uniseriate, wider at base with three extra areolae in a second row.

Fifth instar description: body ovale, glabrous and shiny, covered with tiny star-like processes; withish to yellowish, two longitudinal bands on pro- and mesonotum, tip of hemelytral pads, center of abdomen, legs brown; thorax and abdomen beneath with redish spots. Body length, 2.9; width, 1.67.

Head long armed with seven spines, spines like in adult, long and slender, base stout, directed forwards, the jugal spines shorter than the others; antenniferous processes long and spiny; antennae long and slender, antennal segment measurements: I, 0.10; II, 0.07; III, 0.77; IV, 0.27; bucculae long and narrow, closed in front and extending in front of clypeus; rostrum reaching fourth visible abdominal sternite. 
Pronotum wider than long, produced anteriorly, laterally and lateroposteriorly by acute angles ended by protuberance, anterior protuberance much spiny than lateral and lateroposterior ones, lateral margins roundly excavated between anterior and lateral angles; two short, spiny protuberances in medially near anterior and posterior margins of pronotum, these curved and directed forwards.

Meso- and metanotum with median short spiny protuberance on posterior margin; hemelytral pads with short, stout protuberance on posterior two-thirds of outer margin.

First, second, fifth, sixth, seventh, eighth abdominal terga with median short protuberance near posterior margin; protuberance on first and second terga reddish, somewhat spiny, curved, directed forwards; protuberances on fifth, sixth, seventh, eighth terga short, stout, erect, fifth reddish, sixth blackish and larger than others, somewhat globular, seventh and eighth whitish; fourth, fifth, sixth, seventh, eighth abdominal terga with short, stout protuberance on lateroposterior margin.

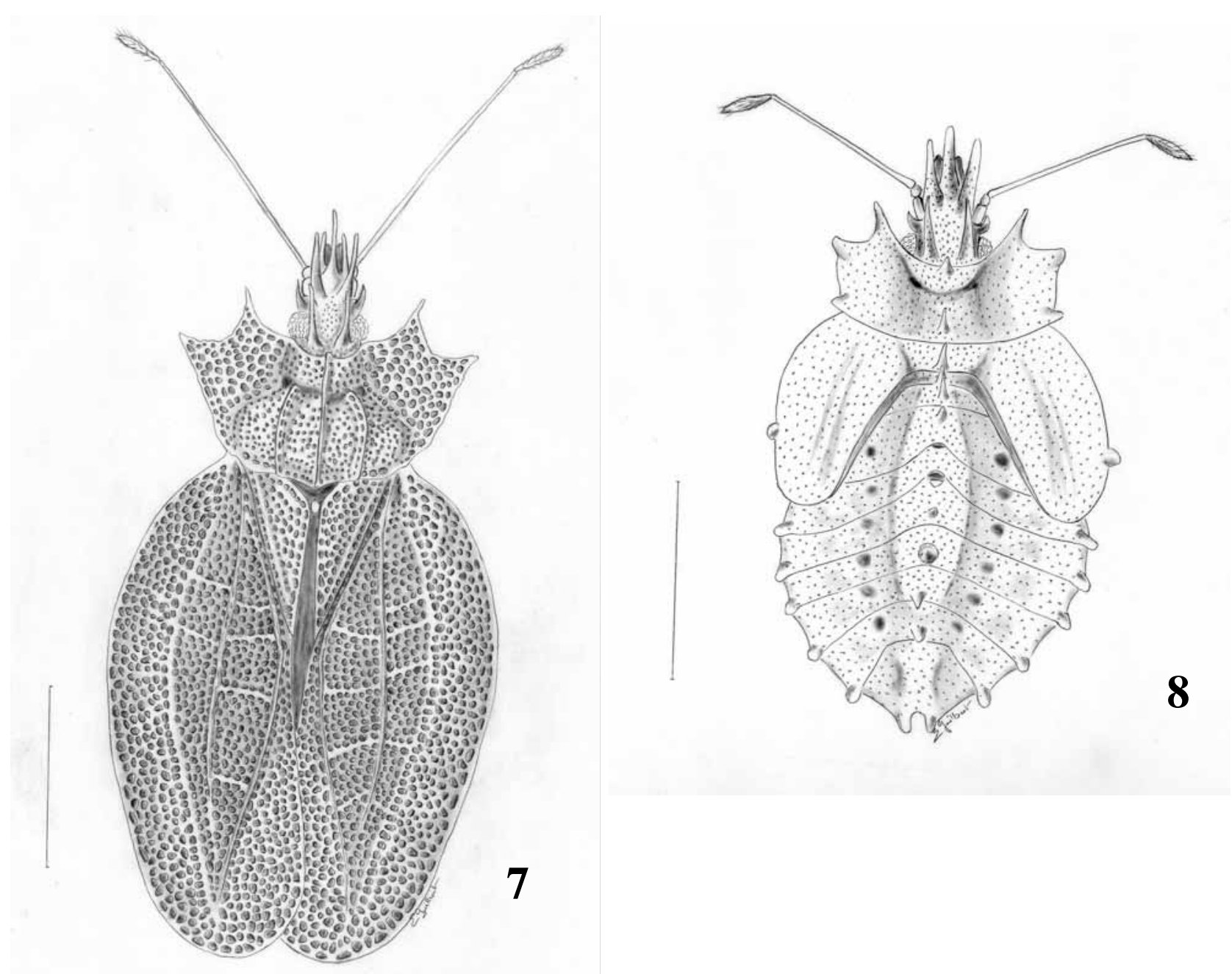

FIGURES 7-8. Phatnoma natensis sp. n., 7 habitus, 8 fifth instar.

Etymology: The name of this species refers to the type locality.

Comments: This species is very similar to $P$. laciniatum Fieber but differs from it by its wider paranota (five to six areolae wide; four wide in $P$. laciniatum), its wider costal area (seven areolae wide; five wide in $P$. laciniatum). It differs also from P. takasago Takeya by its third antennal segment 4.4 times longer than fourth, whereas the third is six times longer than the fourth in P. takasago .Also, in P. laciniatum the third antennal segment is about 4.4 times longer than the fourth.

The fifth instar is known only for P. marmorata Champion and P. maynei Schouteden. They differ in several details. The median protuberance is absent on the metasternum and first abdominal tergum in $P$. marmo- 
rata; the median protuberances on the seventh and eighth terga are much shorter in $P$. maynei; also the posterior protuberances on lateral margins of the terga and hemelytral pads are less distinctly developed than in $P$. marmorata and natensis sp. n. Finally, $P$. natensis $\mathbf{s p .}$. nas jugal spines much longer than does $P$. marmorata, and a little longer than those of $P$. maynei.

\section{Penottus minicystus sp. n.}

(figs. 9, 10, 11)

Material examined: $1 o^{\star}$, Laos, Vientiane prov., Ban Van Eue, 29.IV.1966, light trap, native coll., Rondonishop; 1 ㅇ, Laos, Phong Sali prov., Namak, 8.X.2004, Guilbert coll. MNHN; 1 fifth instar, Laos, Phong Sali prov., Namak, 9.X.2004, Guilbert coll. MNHN.

Adult description: body wide, male clear brown with spots and reticulations darker; paranota and body beneath dark brown; female darker than male and body beneath black. Body length: M, 4.03; F, 4.33; width: M, 1.80; F, 1.90 .

Head bicolored, armed with five spines, frontal and median spines stout, short, occipital spines longer, slender; bucculae long, narrow, mostly uniseriate and narrower anteriorly, open, not joined in front; antennal segment measurements: M, I, 0.23; II, 0.12; III, 1.6, fourth missing; F, I, 0.27; II, 0.13; III, 1.77; IV, 0.37; rostral sulcus straight, narrow, widely open behind; rostrum extending beyond metasternum.

Pronotum long, tricarinate; median carina raised along pronotum; lateral carinae short, concealed anteriorly by paranota; paranota inflated, cystlike, not spherical but flattened on its inner part, longer than high $(1 / \mathrm{h}$ : 1.16) but higher than wide (w/h: 0.83), reaching median carina but not meeting dorsally, covering most of pronotum except posterior process, median carina, hood and collar, areolae large, polygonal; collar raised as a hood, longer than wide, six areolae long; posterior pronotal process somewhat rooflike or elevated medially where median carina.

Hemelytra wide, costal area sinuate, anteriorly bent upwards, irregularly bi- to triseriate, areolae varying in size; subcostal area as wide as costal area, divided into two areas by a boundary vein, outer part uniseriate, areolae small, inner part triseriate; discoidal area longer than half length of hemelytra, seven areoalae wide at widest part, boundary veins raised; sutural area large, eight areolae wide at widest part.

Fifth instar description: body clear brown, covered with tiny starlike processes, center of abdomen, tips of hemelytral pads, body beneath, antennae, base of legs dark brown. Body length, 2.67; width, 1.67 (without spines); max. spines length, 0.65 .

Head short, round, armed with five long, slender, erect spines, spines with small ramifications all along; antenniferous processes short; antennae slender, with small setae all along; antennal segment measurements:, I, 0.23; II, 0.10; III, 1.17; IV, 0.50; clypeus with small setae; bucculae very narrow, not meeting in front; rostrum not seen on carded specimen, however at least reaching mid coxae.

Pronotum wider than long, angulate on lateroposterior margin, armed there with long slender spine, this however shorter than cephalic ones, spines with ramifications all along; lateral margins with two main slender spines shorter than one on posterior tip and also with two to four ramifications, with six-seven additional minor simple spines (without ramifications); posterior margin somewhat angulate medially, with small short spines on areas extending laterally from hemelytral pads; a median pair of simple, short spines near anterior margin.

Meso- and metanota without median spine; hemelytral pads with long, slender spine on posterior part of outer margins, spine same size as cephalic ones, with small ramifications all along; lateral margins with two spines, each half the size of the major one, with one or two ramifications, six to seven additional short spines along margins.

Fourth to ninth abdominal terga each with long, slender spines on posterior angle of lateral margins, 
directed upwards, with small ramification all along; first tergum without median spine; second, fifth to eighth terga with median simple spine (without ramifications), shorter than spines on lateral margins, fifth and sixth longer than others, half the length of lateral ones, second, seventh, eighth each a quarter the length of lateral ones; fifth stouter than others, and dark brown.

Etymology: The name refers to the smaller hood of this species than those of its congeners.

Comments: The two adult specimens were caught in different places, and the female is darker than the male. This species has a small hood, unlike the other Penottus Distant species. This is the first fifth instar of a Penottus species described. The fifth instar was collected in the same place as the female (allotype) but a day after.
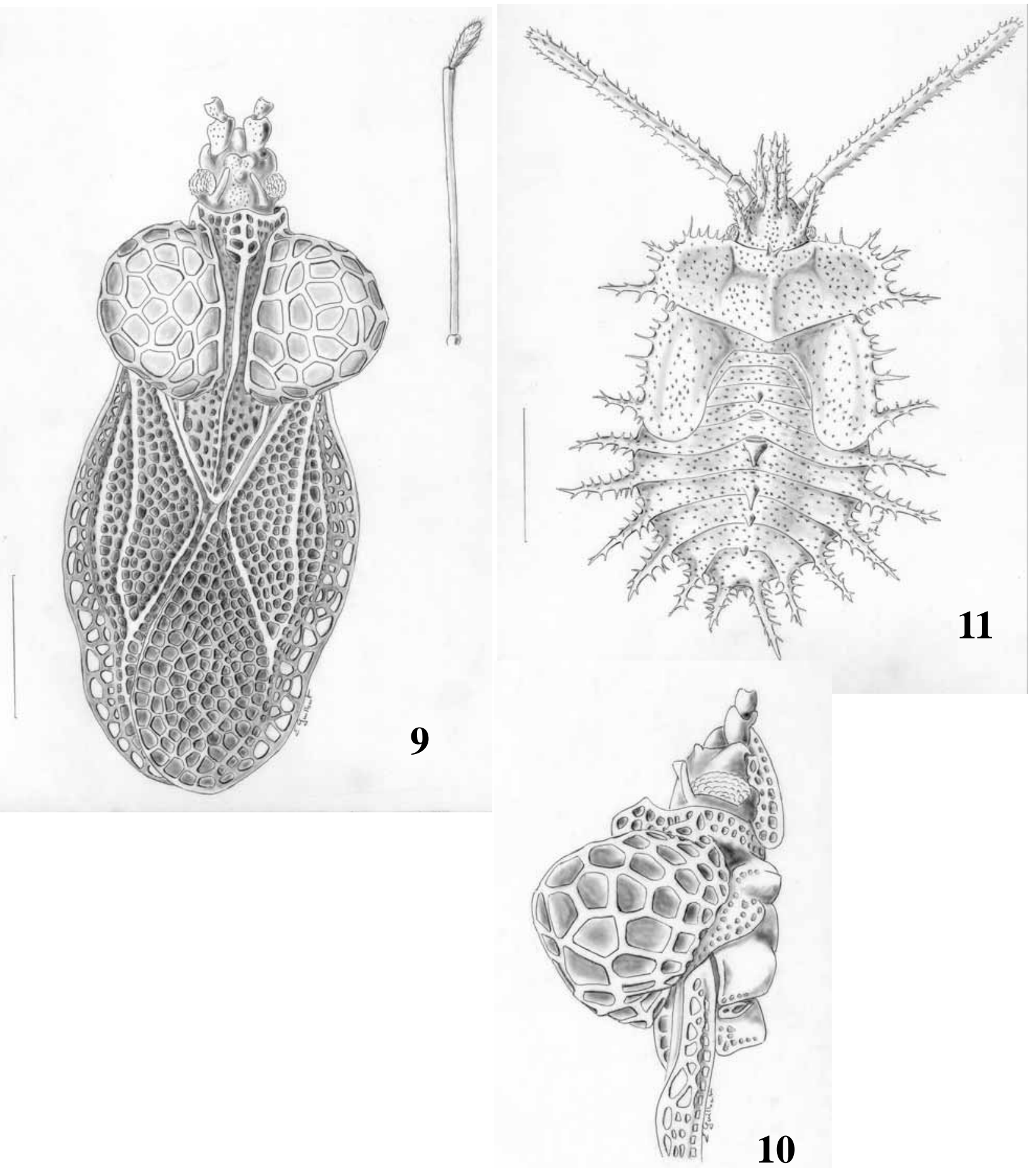

FIGURES 9-11. Penottus minicystus sp. n., 9 habitus, 10 profile, 11 fifth instar. 
Trachypeplus elongatus sp. $\mathbf{n}$.

(figs. 12, 13)

Material examined: $1{ }^{\star}, 1$ ㅇ, Laos, Phong Sali prov., Long Nai Kai, 3.X.2004, Guilbert coll., MNHN; 2 , Laos, Phong Sali prov., Namak, 8.X.2004, Guilbert coll., MNHN.

Description: body narrow, clear brown, punctate portion of pronotum a little darker in some specimens, head, body beneath, two small spots on RM along discoidal area and some other small spots on apex of costal area much darker, almost black. Body length, 3.50- 4.00; width, 1.17-1.33.

Head armed with five spines; occipital spines long, slender, directed forwards, median and frontal spines short, bulbous; antennae long, slender, first two segments stouter, antennal segment measurements: I, 0.17; II, 0.10; III, 1.23; IV, 0.37; bucculae three areolae wide, closed in front; rostral sulcus straight, narrow, almost closed behind; rostrum extending beyond mesosternal coxae, almost reaching hind coxae.
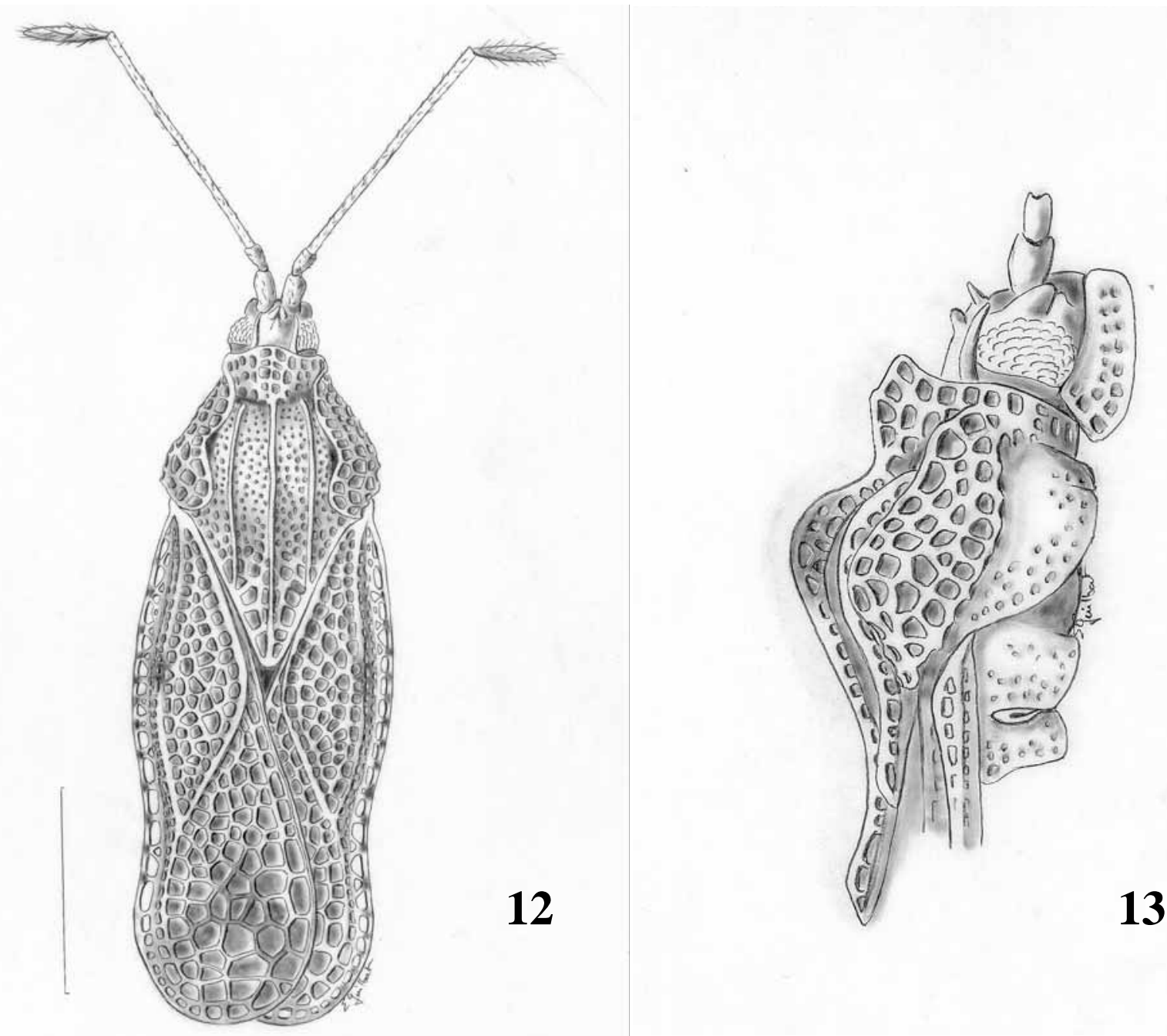

FIGURES 12-13. Trachypeplus elongatus sp. n., 12 habitus, 13 profile.

Pronotum narrow, strongly gibbose, tricarinate, carinae parallel, raised, uniseriate, the areolae small; median carina more elevated on top of pronotum, with larger areolae; collar broad, three areolae wide, top slightly raised and forming a tectiform hood, however, less elevated than top of median carina, paranota wide, five areolae wide at widest part, not reaching lateral carinae, reflexed, in contact with pronotum, except at opposite humeri where raised but not forming a crest.

Hemelytra long, narrow; boundary vein raised; costal area narrow, uniseriate, the areolae irregularly oval, small, some tiny extra inner areolae at base; subcostal area slightly wider than costal area, biseriate, the are- 
olae round, small; discoidal area more than half length of hemelytra, five areolae wide at widest part; sutural area large, seven to eight areolae wide at widest part, these areolae larger than in other areas.

Etymology: The name of this species refers to the fact its body is longer than those of its congeners.

Comments: Trachyplepus elongatus is very similar to T. yunnanus Jing; however, it differs in its longer body (T. yunnanus is $3.27-3.32 \mathrm{~mm}$ ), its paranota being a little more elevated, its rostrum being slightly longer and reaching the hind coxae. T. chinensis Drake \& Poor, also similar to elongatus sp. n., is much smaller $(2.76 \mathrm{~mm})$. T. magnus Jing also resembles this new species and has almost the same length; however, the paranota of T. magnus are anteriorly and posteriorly in contact with lateral carinae, which is not the case in T. elongatus sp. $\mathbf{n}$.

\section{Trachypeplus wapi sp. $\mathbf{n}$.}

(figs. 14, 15)

Material examined: 1 ㅇ, Laos, Wapikhamthong prov., Khong Sedone, Wapi, 30.VIII.1967, native coll., Bishop.

Description: body shiny, yellowish to brownish, a transverse band across hemelytra at posterior third of discoidal area level, spot at apex of costal area, top of median carina darker; legs and body beneath brown; hind tarsi darker. Body length, 3.17; width, 1.20.
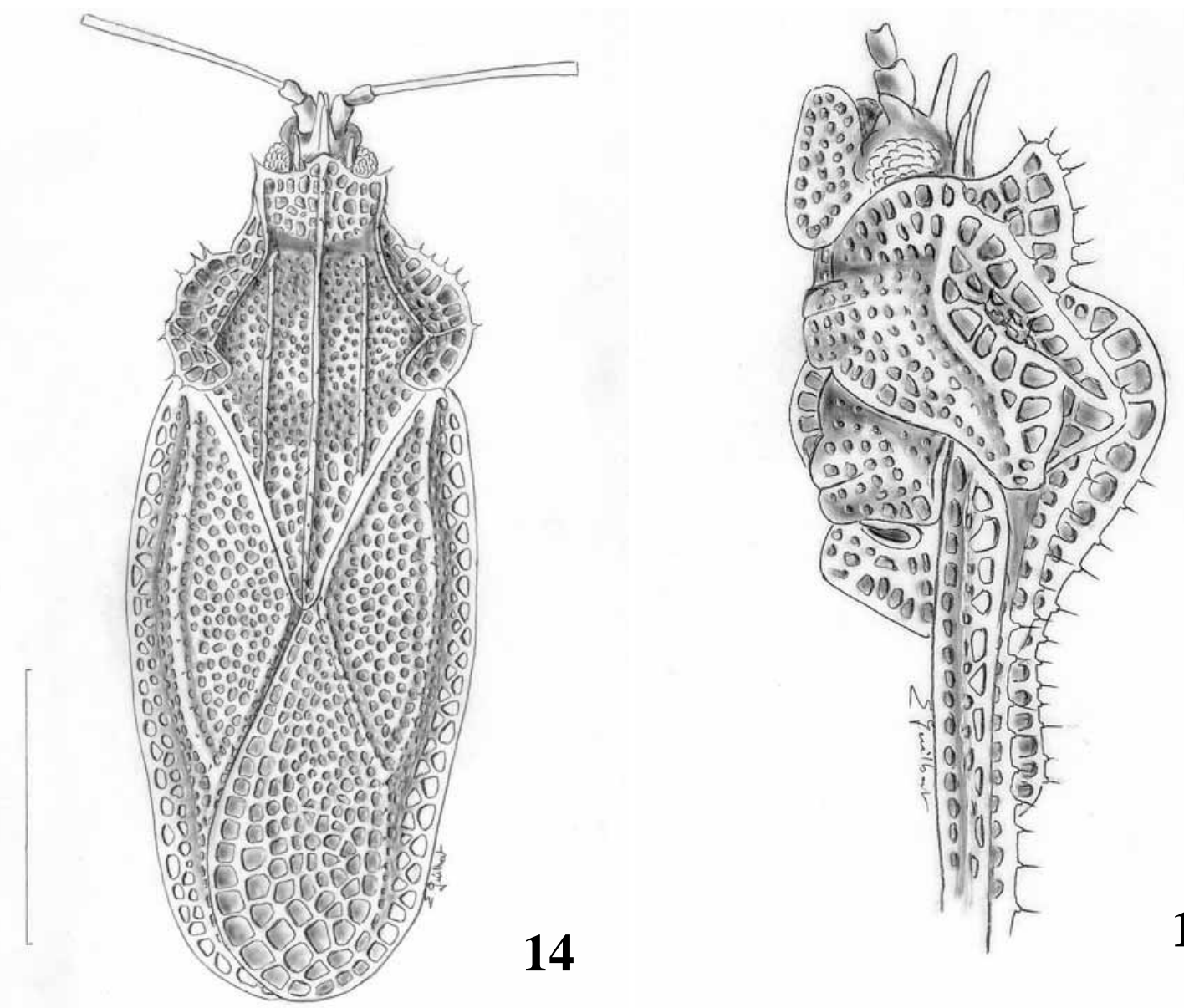

FIGURES 14-15. Trachypeplus wapi sp. n., 14 habitus, 15 profile.

Head pilose on top, armed with five long, slender, erect spines; antennae slender, first two segments stouter, antennal segment measurements: I, 0.13; II, 0.10; III, 0.73; IV missing; bucculae broad, triseriate, closed in front; rostral sulcus straight, narrow, open behind; laminae broad, foliate, its areolae rather large; 
rostrum reaching middle of metasternum.

Pronotum long, gibbose, tricarinate, carinae parallel; median carina raised, uniseriate posteriorly, biseriate anteriorly, its areolae small; lateral carinae raised, uniseriate, less high than median carina; collar broad, three to four areolae wide, raised on top to form a hood, narrow, arced, five areolae long, produced forwards, less high than median carina but higher than top of pronotum; paranota four areolae wide, reflexed, partly resting on pronotum, not in contact with pronotum at opposite humeri, but raised and divided into two convex parts, separated by a transversal crest, the three outer rows also separated from inner row by a longitudinal crest. Carinae, hood, and paranota crests and margins armed with a row of spines regularly spaced.

Hemelytra long, as wide as pronotum, boundary veins raised, areolae almost of same size in all areas; costal area biseriate; subcostal area as wide as costal area, biseriate; discoidal area longer than half hemelytra, eight areolae wide at widest part; sutural area eight areolae wide at widest part; boundary veins $\mathrm{RM}$ and $\mathrm{Cu}$ between subcostal and discoidal areas; discoidal and sutural areas regularly armed with spines regularly spaced.

Etymology: The name refers to the type locality.

Comments: Although this description is based on a single specimen, it does not correspond to any other Trachypeplus species. It is close to T. malloti Drake \& Poor but differs by the spines present on the body while short, the longer cephalic spines, the median carina biseriate on its anterior part, and the presence of a longitudinal ridge on the paranota. It is also close to Pseudurentius borneensis (Péricart) by the form of paranota and the median carina; but it differs by the discoidal area, sutural area, and the paranota being narrower, and the shorter spines on the hemelytra and pronotum.

Comments: Trachypeplus is close to Pseudurentius Péricart. Pseudurentius was raised on the basis of the large pronotal and hemelytral spines (Péricart 1992). However, the variation of the size of the spines within Pseudurentius and Trachypeplus makes the difference between these two genera difficult and blurred.

\section{New records}

\section{Aconchus urbanus Horvàth 1905}

Material examined: 1 ㅇ, Laos, Phong Sali prov., Long Nai Kao, 32004, Guilbert coll., MNHN.

Comments: This species is known from India, Ceylon, Malaya, Philippines, Java, Congo, Kenya, Mozambique, South Africa, and Italy.

\section{Agramma pictipenne (Horvàth 1902)}

Material examined: 1 오 Laos, Ban Theuong, 18km NW of Xieng Khouang, 1035m, 26.VIII.1960, sweeping grass, R.E. Leech coll., Bishop.

Comments: This species is known from New South Wales by the type specimens. It is more similar to Ceratinoderma Stål species than to the other Agramma Stephens species from the region by the coleopteroid shape of the body and the lack of distinct hemelytral areas. Ceratinoderma is known by two species ( $C$. fornicata Stål and C. stali Rodrigues), both from Africa and both lacking distinct hemelytral areas. Agramma pictipenne is also similar to A. kivuensis (Schouteden), which has a narrow and uniseriate costal area, and a slight and almost indistinct RM vein between the subcostal and discoidal areas. Kivuensis former belonged to the genus Ceratinoderma.

\section{Ammianus erosus (Fieber 1844)}

Material examined: 1 우 Laos, received Bishop Museum, 18.VI.1965, M. Rondon coll., Bishop Museum.

Comments: This species is known from the Indo-Malayan region. It varies slightly in the number and 
organization of hemelytral and paranota areolae compared to A. perakensis (Distant); however, it is much smaller.

\section{Baeochila nexa (Distant 1903)}

Material examinated: 1 , , Laos, Phong Sali province, Namak, 92004, A. Soulier-Perkins coll., MNHN.

Comments: Baeochila Drake \& Poor, groups four species: B. elongata (Distant), scitula Drake, dehrana Drake \& Maa, and nexa inhabiting Burma, India, Sri Lanka, and Taiwan. B. nexa inhabits India and differs from the others by its triseriate costal area, which is uniseriate or obsolete in the other Baeochila species.

\section{Belenus bengalensis Distant 1909}

Material examined: $1 \sigma^{x}$, Laos, Vientiane, 1965, light trap, J.L. Gressitt coll., Bishop.

Comment: This species is already known from India, Thailand, and New Guinea.

\section{Corythauma ayyari (Drake 1933)}

Material examined: $6 o^{\star}, 7$ ㅇ, Laos, Vientiane, 26.III.1966J. Sedlacek coll., Bishop.

Comments: This species is known from India and Penang Island, on Jasminum pubescens (star jasmine), Lantana sp., Musa sp. (plantain), and Hedychium sp. (cardamon).

\section{Diconocoris capusi (Horvàth 1906)}

Material examined: $1 \sigma^{x}$, Laos, Sayaboury prov., Sayaboury, 12.XII.1965, native coll., Rondon-- Bishop.

Comments: Diconocoris Mayr contains seven species, all in the Oriental Region. Diconocoris capusi is known from Hong Kong and Vietnam.

\section{Dulinius conchatus Distant 1903}

Material examined: 4 ox, 2 ㅇ, Laos, Vientiane, 26.III.1966, J. Sedlacek coll., Bishop; 1 ㅇ, Laos, Phong Sali prov., Naten, 24.IX.2004, Guilbert coll., MNHN.

Comments: In Dulinius Distant are 12 species, all occurring in the Ethiopian Region except $D$. conchatus, the only species from the Oriental Region. This species was formerly known from Philippines Java, Malaya, India, Sri Lanka, and China.

\section{Elasmognathus helferi Fieber 1844}

Material examined: $1 \sigma^{x}$, Laos, Vientiane prov., Ban Van Eue, 14.IV.1965, J.L. Gressitt coll., Bishop.

Comments: This specimen corresponds to E. helferi, but the costal area is irregularly biseriate or uniseriate, not triseriate as in E. helferi (see Drake \& Davis 1960, fig. 55). Such a difference on a single specimen cannot justify the description of a new species. This species is known from India and Philippines.

\section{Hurdchila mira (Drake \& Poor 1936)}

Material examined: 1 ㅇ, Laos, Vientiane Prov, Phou Kou Khouei, 800m, 1213.IV.1965, J.L. Gressitt coll., Bishop.

Comments: The male has a discoidal area five areolae wide, whereas the female has a discoidal area six areolae wide. The male is darker than the female and the brown band across the middle of the hemelytra is much darker on this specimen. This species is already known from China (Hainan), India, Sri Lanka, and Bhutan.

\section{Ildefonsus ampliatus Péricart 1985}

Material examined: 1 \&, Laos, Phong Sali prov., Naten, 13.X.2004, Guilbert coll. MNHN.

Comments: Described from Nepal, this species is known by the type specimens and this one. The speci- 
men from Laos is darker than the one from Nepal. ldefonsus Distant groups six species all restricted to the Oriental region: Burma, China (Yunnan, Hubei, Zhejiang), India, Java, Laos, and Nepal.

\section{Physatocheila marginata (Distant 1909)}

Material examined: 1 ㅇ, Laos, Sayaboury, 15.IV.1965, J.L. Gressitt coll., Bishop.

Comments: This species is known from The Philippines (Luzon) and India.

\section{Pseudurentius borneensis Péricart 1986}

Material examined: 1 ㅇ, Laos, Vientiane prov., Ban Van Eue, 31.XII.1965, natice coll., malaise trap, Rondon--Bishop. 1 ㅇ, Laos, Vientiane prov., Ban Van Eue, 31.XII.1965, J.L. Gressitt coll., Bishop.

Comments: This species is already known from North Borneo. Formerly belonging to the genus Trachypeplus, this species was transferred by Péricart (1992) to the genus Pseudurentius Péricart (with P. elegens Péricart) because of the short spines on the paranota and hemelytral margins. The specimens from Laos differ slightly by the more sharply developed spines, the darker color patterns, the higher hood, and the sutural area which is seven-eight areolae broad, not eight-nine. Also, the paranota are four areolae wide, whereas they are four to five areolae wide in the type of $P$. borneensis.

\section{Stephanitis (Norba) outouana Drake \& Maa 1953}

Material examined: 1 ㅇ, Laos, Vientiane prov., Ban Van Eue, 30.XI.1966, native coll., Bishop.

Comments: This specimen has all the characteristics of $S$. outouana, except that it is much larger (4.17 $\mathrm{mm}$ ) and its rostrum reaches the hind coxae and almost the abdomen. It is closely allied to $S$. chinensis Drake but has divergent hemelytra. It is also closely allied to $S$. bhutanensis Péricart but has also divergent hemelytra and a longer fourth antennal segment. This single specimen cannot justify the description of a new species and is therefore considered provisionally as S. outouana. This species is known by the type series from China (Fukien).

\section{Stephanitis (Stephanitis) laudata Drake \& Poor 1953}

Material examined: 1 우 Laos, Vientiane prov., Phou Kou Khouei, 800m, 1213.IV.1965, J.L. Gressitt coll., Bishop; 1 ㅇ, Laos, Vientiane prov, Ban Van Eue, 31.XII.1965, Malaise trap, native coll., RondonBishop.

Comments: This species is already known from China (Hainan Island) and Taiwan.

\section{Stephanitis (Stephanitis) typica (Distant 1903)}

Material examined: $2 \sigma^{\star}$, Sedone prov., Paksong, 18.V.1965, P.D. Ashlock coll., Bishop.

Comments: This species is widespread in the Oriental region, but these specimens are the first record of the species from Laos.

\section{Trachypeplus chinensis Drake \& Poor 1936}

Material examined: $1{ }^{\star}$, Laos, 710 m, Phou-kow-kuei, N of Vientiane, 17.IV.1965, J.L. Gressitt coll., Bishop.

Comments: This species is known from Hainan Island, Hong Kong, and Vietnam. This specimen differs from the other specimens of T. chinensis by being shorter, and having a smaller but distinct hood. Trachypeplus includes ten species, all restricted to the Oriental region, New Guinea, and the Philippines.

\section{Trachypeplus yunnanus Jing 1980}

Material examined: 1 + , Laos, Vientiane prov., Ban Van Eue, 30.XI.1965, native coll., Bishop.

Comments: This species was described from Yunnan province (China). It is similar to T. chinensis Drake 
\& Poor but differs from it by the longer body, the shorter cephalic spines, the longer rostrum, a portion of the RM boundary vein not being elevated, and the costal area which has some additional tiny areolae in a partial second inner row.

\section{Urentius hystricellus (Richter 1869)}

Material examined: $1{ }^{\star}, 2$ ㅇ, Laos, Sedone prov., Pakse, 11.V.1965, P.D. Ashlock coll., Bishop.

Comments: This species is already known from India, Sri Lanka, and Africa: Senegal, Egypt, Kenya, Sudan Republic, Mozambique, Zimbabwe, Uganda, Niger, and Nigeria.

\section{Key to genera and species}

Because of the paucity of work on the fauna of Laos, more species undoubtedly occur in this country (probably many more). Therefore, this study and that of Lis (1999) should be considered are preliminary. To help in further study of this fauna, I present here a key to genera and species of the known Laotian Tingidae.

1 Head largely produced in front of eyes; antennal segments 1 and 2 not surpassing apex of head

Head short declivent, antennal segment 1 surpassing apex of head.....

(Cantacaderinae) 2

Hemelytra with uniseriate stenocostal area (Tinginae) 4

Hemelytra without stenocostal area.

(Cantacaderini) 3

3 Anterior angle and lateral margin of paranota projected spinelike... Spinelike projections on pronotal margins absent (Phatnomini) Phatnoma natensis sp.n. Pseudophatnoma laosana ${ }^{1}$ Cantacader hirsutus ${ }^{2}$

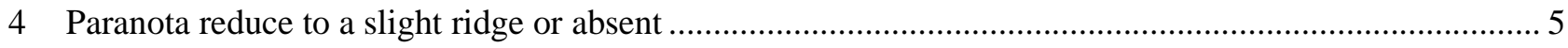

Paranota present

5 Body coleopteroid, hemelytra strongly concave. Agramma pictipenne

Body oblong, hemelytra not strongly concave Agramma biseriata sp. $\mathbf{n}$.

6 Paranota narrow, uniseriate. Paracopium longnaimai sp. $\mathbf{n}$.

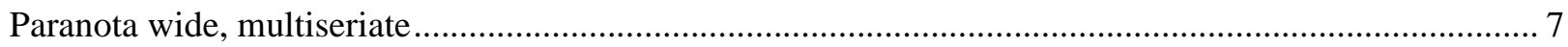

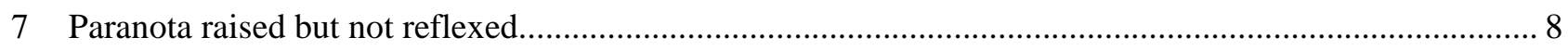

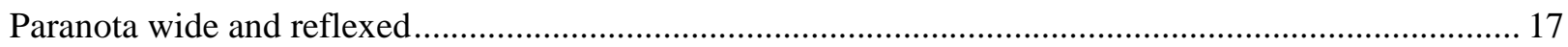

$8 \mathrm{RM}$ vein not swollen, areolate structures not completely hyaline ..................................................... 9

$\mathrm{RM}$ vein swollen in the middle, areolate structures hyaline .............................................................. 13

9 Occipital and median cephalic spines bifid ................................................................ Belenus bengalensis

Cephalic spines, when present, never bifid................................................................................. 10

10 Hood, anterior part of median carina inflated, forming a large cyst............................. Corythauma ayyari

Hood, if cystlike, restricted to collar, median carina not inflated ....................................................... 11

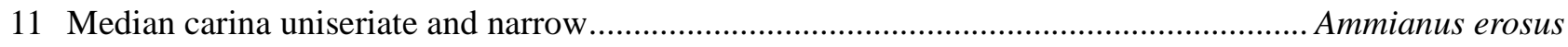

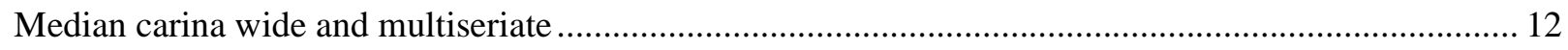

12 Margins and veins of pronotal and hemelytral structures spinose......................Lasiacantha gressitti sp. n. Margins and veins of pronotal and hemelytral structures not spinose..........................Ildefonsus ampliatus

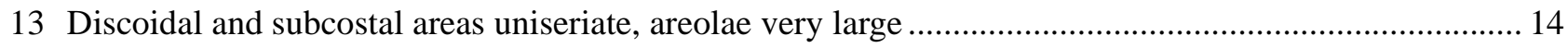
Discoidal and subcostals area pluriseriate ……….................................................................. Stephanitis 15

14 Posterior pronotal process cystlike ..................................................................................enchus urbanus

Posterior pronotal process not cystlike ........................................................................ Dulinius conchatus

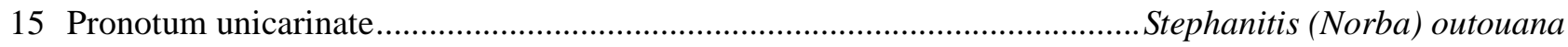
Pronotum tricarinate ................................................................................ Stephanitis (Stephanitis) 16 
16 A subapical cross-band, a cross-band near base, and upper row of areolae of median carina dark fuscous. Stephanitis laudata

All areolae hyaline and clear Stephanitis typica

17 Paranota not reaching onto pronotum but forming two cysts covering most of it................................... 18

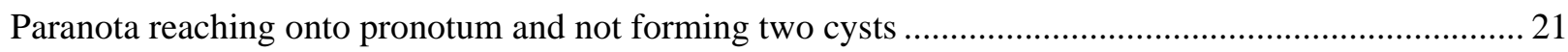

18 Paranota forming two raised and elongate columns, ending in two bulbous cysts at apex.....

Diconocoris capusi

Paranota forming two cysts of different shapes.

19 Paranota developed as to form two cysts covering most of pronotum Penottus minicystus sp. $\mathbf{n}$.

Paranota developed as to form two circumvolutions covering most of pronotum . Elasmognathus 20

20 Discoidal area seven areolae wide and costal area irregularly biseriate..... Elasmognathus laosensis $\mathbf{s p .} \mathbf{n}$. Discoidal area nine areolae wide and costal area triseriate Elasmognathus helferi

21 Hood present, much higher than median carina Baeochilanexa

Hood absent or small 22

22 Paranota meeting median carinae, body armed with long spines Paranota not meeting median carinae Urentius hystricellus

23 Pronotum slightly shorter than hemelytra. 23 Pronotum slightly shorter than three-quarter length of hemelytra. Hurdchila mira

24 Median carina partly biseriate. 24 Median carina mostly uniseriate Pseudurentius borneensis

25 Paranota outer margin completely in contact with pronotum. 25 Paranota outer margin elevated and not touching pronotum on top. Physatocheila marginata 6 Margins and some veins of pronotum and hemelytra armed with spines Trachypeplus 26 Margins and some veins of pronotum and hemelytra without spines. Trachypeplus wapi $\mathrm{sp} . \mathrm{n}$.

$27 \mathrm{RM}$ vein elevated near middle and at apex of discoidal area RM vein not elevated. Trachypeplus chinensis 8 Body at least $3.50 \mathrm{~mm}$ long. Body at most $3.35 \mathrm{~mm}$ long. Trachypeplus yunnanus

'The genus Pseudophatnoma is partly characterized by having a projection of the posterior pronotal margin covering the scutellum (Blöte 1945; Froeschner 1996); however, this is not the case in P. laosana Lis, in which the posterior projection only partly covers the scutellum (Lis 1999). In addition, P. corniculata Blöte has a hood which is not mentioned either in the description or in the drawing because the description is based on a single specimen whose hood was broken (Péricart 1991). Thus the key to species of Pseudophatnoma proposed by Lis (1999) should be modified.

${ }^{2}$ Cantacader hirsutus is the only pilose species of the genus (Lis 2003).

\section{Discussion}

The Laotian fauna has been and remains very poorly known and studied. Twenty-eight species of Tingidae are now known from Laos, and these are from seven collection sites (Khong Sedone and Pakse in Sedone Prov., Van Ban Eue and Phou Kou Khouei in Vientiane Prov., Ban Theuong in Xieng Khouang Prov., Sayaboury in Sayabouri Prov., and Namak, Naten, Long Nai Kao, Long Nai Mai in Phong Sali Prov.). Four species are relatively widespread: A. urbanus, D. conchatus, and $U$. histricellus occur in the Oriental and Ethiopian Regions; and S. typica is common in the Oriental and east Palearctic Region. The other species are restricted to oriental countries and mainly to boundary countries (South China, Vietnam).

The fauna of the counties near Laos is also very poorly known: No study deals specifically with the Burmese, Cambodian, Thai, and Vietnamese fauna. Only south China (including Yunnan Province) has recently 
been considered in several studies on Tingidae fauna (Jing 1980; Li \& Zheng 2001; 2002; 2006). Thus, many species certainly remain to be discovered in these countries.

\section{Acknowledgements}

I am greatly indebted to G. Nishida (Bishop Museum) for the loan of material from the Bishop Museum; and to the Pluri-Formation Program Etat et structure phylogénéique de la biodiversité actuelle et fossile (MNHN/ MENRT) and the Phong Sali Forest Conservation and Rural Development Project, which funded the survey to Phong Sali Province, Laos (Sept/Oct. 2004). I thank also A. Soulier-Perkins (MNHN, Paris) for her help in catching Tingidae during the survey in Phong Sali.

\section{References}

Blöte, H.C. (1945) Catalogue of the Berytidae, Piesmatidae and Tingidae in the Rijksmuseum van Natuurlijke Historie. Zoologische Mededeelingen, 25, 72-92.

Froeschner, R. C. (1996) Lace bug genera of the world, I: introduction, subfamily Cantacaderinae (Heteroptera: Tingidae). Smithsonian Contribution to Zoology, 574, 1-43.

Jing, X.L. (1980) New species of Chinese Tingidae (Hemiptera: Heteroptera). Acta Zootaxonomica Sinica, 5, 395-403.

Li, C.R. \& Zheng, L. Y. (2001) Genus Cantacader Amyot et Serville from China (Hemiptera: Tingidae). Acta Zootaxonomica Sinica, 26, 94-199.

Li, C.R. \& Zheng, L.Y. (2002) A new genus and new species of Phatnomini from China (Hemiptera: Tingidae). Acta Zootaxonomica Sinica, 45, 648-650.

Li, C.R. \& Zheng, L.Y. (2006) Note on the genus Ildefonsus Distant, with description of a new species (Hempitera, Tingidae) from China. Acta Zootaxonomica Sinica, 31, 580-584.

Lis, B. (2003) Revision of the genus Cantacader Amyot et Serville, 1843 (Hemiptera: Heteroptera: Cantacaderidae). Polski Pismo Entomologiczne, 72 suppl, 1-222.

Lis, B. (1999) Two new species of the subfamily Cantacaderinae from Laos (Heteroptera: Tingidae). Polski Pismo Entomologiczne, 68, 23-28.

Péricart, J. (1991) Cantacaderinae de Thailande, Born? et Palawan: Genres nouveaux esp?es nouvelles ou int?essantes ainsi qu'une nouvelle synonimie (Hemiptera, Tingidae). Revue Suisse de Zoologie, 98, 33-50.

Péricart, J. (1992) Tingidae (Tinginae) d'Arabie, de la r?ion orientale et d'Australie, avec la description d'un genre nouveau et de 14 esp?es nouvelles (Hemiptera). Entomologica Basiliensia, 15, 45-86. 